\title{
Symptom awareness measures for breast and cervical cancer in sub-Saharan Africa: A scoping review
}

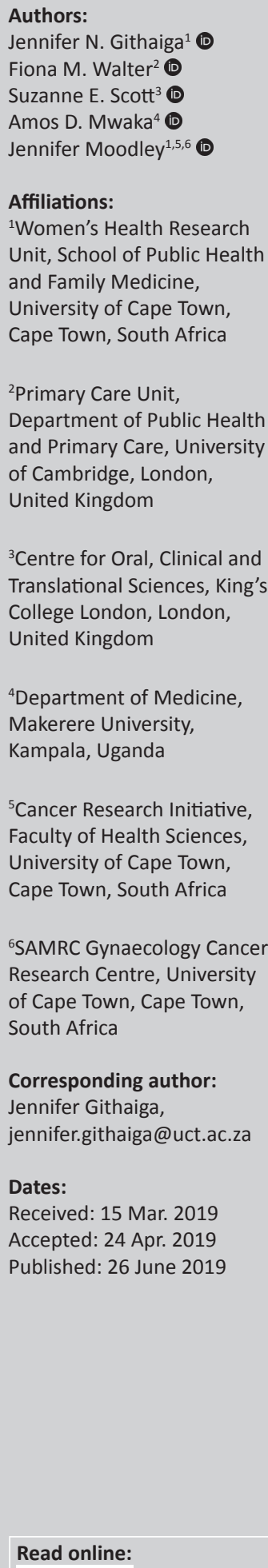

Corresponding author: Jennifer Githaiga, jennifer.githaiga@uct.ac.za

Dates:

Received: 15 Mar. 2019

Accepted: 24 Apr. 2019

Published: 26 June 2019

Read online:

Background: In sub-Saharan Africa (SSA), breast cancer is the most commonly diagnosed cancer among women, while cervical cancer remains the leading cause of cancer death. Women often fail to recognise or misinterpret possible symptoms, so breast and cervical cancer symptom awareness information can promote timely help-seeking behaviour, diagnosis and start of treatment.

Aim: To identify tools that have been utilised to measure breast and cervical cancer symptom awareness in SSA and to establish if such tools have been validated in SSA populations.

Methods: A scoping review of articles published between January 1997 and February 2017, written in English and describing primary research in breast and/or cervical cancer symptom awareness-related topics in SSA contexts, was undertaken across five databases. The approach was supported by Colquhoun et al.'s methodological framework for scoping reviews.

Results: A total of 41 studies were included from 11 SSA countries. Almost half (20/41) used breast and/or cervical cancer symptom awareness tools but did not report on tool validation processes. The rest $(21 / 41)$ made reference to some tool validation, yet only two reported a detailed account of their tool validation processes. One explored lay perceptions of breast cancer, while the other sought to establish the validity and reliability of a UK tool in a Kenyan context.

Conclusion: The findings point to the dearth of comprehensively validated and culturally relevant tools to measure breast and cervical cancer symptom awareness in the SSA context. They have informed the development and validation of an African Women Awareness of CANcer (AWACAN) tool, which can support the development and evaluation of interventions relevant to the SSA context.

Keywords: scoping review; breast and cervical cancer; symptom awareness measures; sub-Saharan Africa.

\section{Introduction}

Breast and cervical cancers are the leading cause of cancer morbidity and mortality in women. In sub-Saharan Africa (SSA), breast cancer is the most commonly diagnosed cancer among women, while cervical cancer remains the leading cause of cancer death. ${ }^{1}$ Yet, if diagnosed early, both cancers are treatable with curative intent. Worldwide, most cancers $(85 \%-90 \%)$ are diagnosed following symptomatic presentation. ${ }^{2}$ Consequently, understanding processes related to cancer symptom epidemiology, symptom awareness and responses to symptoms are important in developing interventions to promote timely cancer diagnosis. For both breast and cervical cancers, women often fail to recognise or misinterpret these symptoms or wait until symptoms (and disease) progress before they seek medical attention. ${ }^{3,4,5,6}$ For example, patients in Nepal have been shown to be more likely to recognise vaginal bleeding and seek care for symptoms, in contrast to recognising foul smelling vaginal discharge. ${ }^{5}$ For breast cancer, women are more likely to recognise and seek care for breast lumps in contrast to non-lump symptoms. ${ }^{6}$ There is evidence that interventions to increase awareness lead to better outcomes. ${ }^{7}$ For instance, a Malaysian study reported earlier help-seeking for breast and cervical cancers following an intervention targeted at raising public awareness of symptoms of these cancers. ${ }^{8}$ This suggests that breast and cervical cancer symptom awareness and interpretation can promote timely help-seeking behaviour, diagnosis and start of treatment.

How to cite this article: Githaiga JN, Walter FM, Scott SE, Mwaka AD, Moodley J. Symptom awareness measures for breast and cervical cancer in sub-Saharan Africa: A scoping review. S. Afr. j. oncol. 2019;3(0), a78. https://doi.org/10.4102/sajo.v3i0.78

Copyright: ( 2019. The Authors. Licensee: AOSIS. This work is licensed under the Creative Commons Attribution License. 
Accurate measurement of cancer symptom awareness, knowledge and beliefs using validated tools would enable precise measurement of the impact of cancer awareness interventions. Against this background, we conducted a scoping review to identify tools which have been utilised to measure breast and cervical cancer symptom awareness in SSA and evidence of their validity. Scoping reviews differ from systematic reviews in scope, criteria and quality assessment. ${ }^{9,10,11}$ Scoping reviews cover a broader scope than systematic reviews which have a more clearly defined, narrow scope. This renders scoping reviews useful when attempting to encapsulate and disseminate findings from a diverse body of knowledge. Inclusion and exclusion criteria in a scoping study are developed during study selection unlike in a systematic review where such criteria are predetermined prior to study selection, during protocol development. Scoping reviews present evidence based on key themes but do not delve into assessment of the quality of such evidence, as is the case in systematic reviews. Scoping reviews may be conducted as a preamble - to determine if it is necessary to conduct a full systematic review - or as an autonomous exercise, as we did in this review.

\section{Methods}

The review was guided by two questions: (1) Which tools have been used to measure symptom awareness in SSA? (2) Have these tools been validated in any SSA populations? Following Colquhoun et al., ${ }^{12}$ the review process incorporated the first five stages of Arksey and O'Malley's six-stage framework for conducting scoping reviews ${ }^{9}$ with Levac et al.'s enhancements of each stage. ${ }^{10}$ The five stages are as follows: stage 1: identifying the research question, purpose and objectives of the scoping study; stages 2-4: identifying relevant studies, study selection and charting the data, respectively; and stage 5: collating, summarising and reporting the results.

Identification of relevant studies commenced with a basic search for the terms 'breast cancer, cervical cancer, awareness, beliefs, measures, Africa' on Web of Science, Scopus and Ebscohost electronic databases. We then sifted through key studies for potential broader search terms, which generated a list of terms (see Appendix 1). A scoping review of literature was then undertaken in PubMed, Web of Science, Ebscohost, Scopus and Cochrane databases. This process entailed refining the search strategy with the aim of generating as many relevant articles as possible. The final search strings contained the terms 'breast; cervix*; cancer; neoplasm; symptom*; sign; knowledge; perception*; appraisal; understand*; beliefs; attitudes; behavio $\$ \mathrm{r}$; tool; scale; measure* $]^{\prime}$ in various combinations, with the Boolean phrases AND/OR. The database search was supplemented by articles identified by searching through reference lists of key articles.

We included peer-reviewed journal articles published between January 1997 and February 2017, written in English and describing primary research in breast and/or cervical cancer symptom awareness-related topics in SSA contexts. Given the focus on tool validation which involves evaluating 'if the measurement tool employed actually measures the intended research concept or construct or if the measurement tools used to quantify the variables provides table or consistent responses', ${ }^{13}$ that is, validity and reliability, respectively, the research team limited articles to quantitative research studies. The exclusion criteria were articles in languages other than English, non-peer-reviewed articles and book chapters, grey literature, qualitative studies and studies from low-and-middle-income countries outside SSA. Selection of studies involved consultations among the authors who met as a team to establish consensus.

\section{Ethical considerations}

This article followed all ethical standards for a research without direct contact with human or animal subjects.

\section{Results}

The PRISMA flow diagram and checklist (see Figure 1) 1 ) $^{14}$ demonstrate our search strategy and included studies.

Forty-one studies were included. In these studies, cancer awareness is discussed from various perspectives including symptom knowledge, awareness, perceptions and attitudes about breast cancer, cervical cancer or cancer in general, including risk factors. The studies also discussed healthcare use including delays in seeking treatment, pathways to treatment and screening practices.

\section{Tools and validation processes}

Twenty of the 41 studies used symptom awareness tools but gave no detail on tool validation processes $^{3,4,15,16,17,18,19,20,21,22,23,24,25,26,27,28,29,30,31,32}$ (see Table 1). Twenty-one studies referred to some tool validation processes. Of these, 19 had limited detail of validation (see Table 2), $33,34,35,36,37,38,39,40,41,42,43,44,45,46,47,48,49,50,51,52$ and two documented thorough validation processes (see Table 3). ${ }^{53,54}$ Regarding the 19 studies that made some limited reference to validation, two studies noted that they used validated tools but did not test the validity of the tools for themselves. ${ }^{33,34}$ Three studies tested for internal reliability. ${ }^{35,36,37,38}$ One of the three studies published two articles each of which assessed test-retest reliability with 20 women. ${ }^{35,36}$ The second study assessed test-retest reliability with an unspecified group of women with similar characteristics to the study sample, ${ }^{37}$ while the third study utilised Cronbach's alpha internal reliability test. ${ }^{38}$

Fourteen studies utilised pilot testing $39,40,41,42,43,44,45,46,47,48,49,50,51,52$ as follows: two studies documented that they pilot tested their tools but gave no further information ${ }^{39,40}$; one study specified that they used pilot testing to test reliability of their tool $^{41}$; one study alluded to their pilot test serving as a reliability (stability) test by identifying their participants as a 


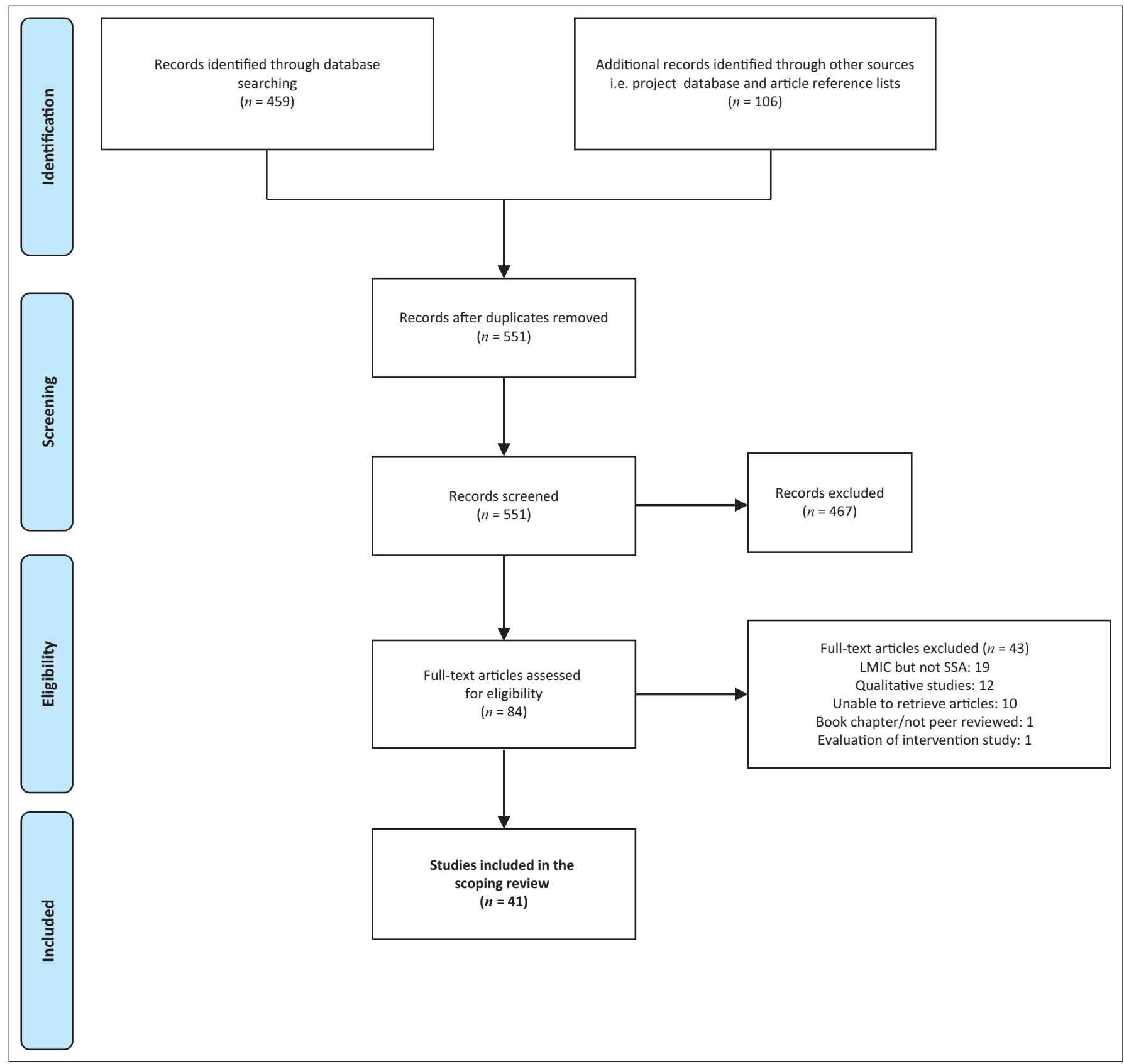

Source: Moher D, Liberati A, Tetzlaff J, Altman DG, Prisma Group. Preferred reporting items for systematic reviews and meta-analyses: The PRISMA statement. PLoS Med. $2009 ; 6$ (7):e1000097. LMIC, low and middle-income countries; SSA, sub-Saharan Africa

FIGURE 1: PRISMA flow diagram. ${ }^{14}$

separate group from that in the actual study ${ }^{42}$; six studies tested content validity using pilot tests followed by modification of items based on outcomes of the pilot tests ${ }^{43,44,45,46,47,48}$; four studies utilised piloting for a combination of validity and reliability tests. ${ }^{49,50,51,52}$ For instance, use of peer review $^{49}$ and expert review ${ }^{50}$ to test for content validity or testing construct validity by structuring content in line with relevant subject literature. ${ }^{49}$ One study provided additional information on the number of items discarded and those retained after piloting, with content categories for the latter. ${ }^{50}$

Table 3 shows the two articles that gave a detailed account of their validation processes. ${ }^{53,54}$ Both articles reported a study conducted by a research team from the Academic Model
Providing Access to Healthcare (AMPATH) Oncology Institute, based in Eldoret, Kenya. One explored lay perceptions of breast cancer, ${ }^{53}$ while the other sought to establish the validity and reliability of the UK Breast Cancer Awareness Measure (BCAM) ${ }^{55}$ in a Kenyan context. ${ }^{54}$

Naanyu et al. ${ }^{53}$ modified BCAM items by adding open-format questions relating to symptoms, severity and treatment of breast cancer, to suit their Kenyan audience. The specific questions were not detailed in the article. Furthermore, two open-ended questions were added to the tool as follows: (1) 'What are some beliefs, opinions and traditions that you have heard from others about breast cancer?' (2) 'In your opinion, what are some of the early warning signs of breast 
TABLE 1: Symptom awareness tools identified, no validation details provided.

\begin{tabular}{|c|c|c|c|c|c|}
\hline Study & Country & Focus & Design & Tools & Validated \\
\hline Mukama et al. ${ }^{15}$ & Uganda & $\begin{array}{l}\text { Knowledge and attitudes towards cervical cancer } \\
\text { (CC) prevention }\end{array}$ & $\begin{array}{l}\text { community-based } \\
\text { cross-sectional survey }\end{array}$ & Questionnaire & No \\
\hline Ndejjio et al. ${ }^{16}$ & Uganda & Uptake of CC screening \& associated factors & $\begin{array}{l}\text { cross-sectional descriptive } \\
\text { survey }\end{array}$ & Semi-structured questionnaire & No \\
\hline Azubuike and Unuoha ${ }^{17}$ & Nigeria & $\begin{array}{l}\text { Breast cancer }(B C) \text { awareness, risk factors, signs \& } \\
\text { symptoms, preventive measures, attitudes, cure } \\
\text { prevention, causes, practices, and associated } \\
\text { factors }\end{array}$ & $\begin{array}{l}\text { cross-sectional community } \\
\text { survey }\end{array}$ & $\begin{array}{l}\text { Semi-structured questionnaire } \\
\text { developed from previous published } \\
\text { studies (studies not cited) }\end{array}$ & No \\
\hline Dreyer et al. ${ }^{18}$ & South Africa & $\begin{array}{l}\text { School based human papillomavirus (HPV) } \\
\text { vaccination \& CC knowledge }\end{array}$ & $\begin{array}{l}\text { cross-sectional school } \\
\text { based study }\end{array}$ & $\begin{array}{l}\text { Interviewer-administered structured } \\
\text { questionnaire }\end{array}$ & No \\
\hline Ali-Risasi et al. ${ }^{19}$ & DRC & $\begin{array}{l}\text { Knowledge, attitude \& practice about cancer of } \\
\text { the uterine cervix }\end{array}$ & cross-sectional survey & Interviewer-administered questionnaire & No \\
\hline Morema et al. ${ }^{20}$ & Kenya & Determinants of CC screening services uptake & cross-sectional survey & $\begin{array}{l}\text { Self-administered structured } \\
\text { questionnaires }\end{array}$ & No \\
\hline Ahmed et al. ${ }^{21}$ & Nigeria & Knowledge, attitude \& practice of CC screening & $\begin{array}{l}\text { cross-sectional descriptive } \\
\text { survey }\end{array}$ & $\begin{array}{l}\text { Questionnaire (closed \& open-ended } \\
\text { questions) }\end{array}$ & No \\
\hline Azubuike and Okwuokei ${ }^{22}$ & Nigeria & $\begin{array}{l}\text { Level of BC awareness, attitudes and practices } \\
\text { towards early detection strategies }\end{array}$ & $\begin{array}{l}\text { cross-sectional descriptive } \\
\text { survey }\end{array}$ & $\begin{array}{l}\text { Self-administered semi-structured } \\
\text { questionnaire with } 23 \text { items developed } \\
\text { from previous published studies } \\
\text { [studies not cited] }\end{array}$ & No \\
\hline Sudenga et al. ${ }^{23}$ & Kenya & CC: Knowledge, attitudes, practices \& perceived risk & cross-sectional survey & Interviewer-administered questionnaire & No \\
\hline Irurhe et al. ${ }^{24}$ & Nigeria & Knowledge $\&$ awareness of $B C$ & cross-sectional survey & Self-administered questionnaire & No \\
\hline Kahesa et al. ${ }^{25}$ & Tanzania & Determinants of acceptance of CC screening & cross-sectional survey & Structured questionnaire & No \\
\hline Were et al. ${ }^{26}$ & Kenya & CC screening: Perceptions of risk \& barriers & cross-sectional survey & Semi-structured questionnaire & No \\
\hline Maree and Wright ${ }^{27}$ & South Africa & $\begin{array}{l}\text { Cancer understanding, awareness, and health } \\
\text { seeking behaviours }\end{array}$ & $\begin{array}{l}\text { exploratory, contextual, } \\
\text { quantitative door-to-door } \\
\text { survey }\end{array}$ & Structured questionnaire & No \\
\hline Clegg-Lamptey et al. ${ }^{3}$ & Ghana & BC: late presentation and treatment absconding & cross-sectional survey & Interviewer-administered questionnaire & No \\
\hline Osime et al. ${ }^{28}$ & Nigeria & BC knowledge, attitudes and practice & cross-sectional survey & $\begin{array}{l}\text { structured self-administered } \\
\text { questionnaire }\end{array}$ & No \\
\hline Tebeu et al. ${ }^{29}$ & Cameroon & CC: attitude \& knowledge & hospital-based survey & Questionnaire & No \\
\hline Ukwenya et al. ${ }^{4}$ & Nigeria & Delayed treatment of symptomatic BC & cross-sectional study & Structured open-ended questionnaire & No \\
\hline Kazaura et al..$^{30}$ & Tanzania & $\begin{array}{l}\text { Health seeking behaviour among patients with } \\
\text { cancer }\end{array}$ & hospital-based survey & $\begin{array}{l}\text { Structured and semi-structured } \\
\text { interviews }\end{array}$ & No \\
\hline Kidanto et al. ${ }^{31}$ & Tanzania & CC: Knowledge and attitudes of female patients & $\begin{array}{l}\text { comparative cross- } \\
\text { sectional survey }\end{array}$ & Structured questionnaire & No \\
\hline Pillay ${ }^{32}$ & South Africa & BC \& CC: Awareness & community-based survey & $\begin{array}{l}\text { Interviewer-administered structured } \\
\text { questionnaire (fixed format) - sample } \\
\text { questions included; informed by } \\
\text { oncology literature (not specified) }\end{array}$ & No \\
\hline
\end{tabular}

TABLE 2: Symptom awareness tools identified, some validation details provided.

\begin{tabular}{|c|c|c|c|c|c|}
\hline Study & Country & Focus & Design & Tools & Evidence of validity \\
\hline Omotara and Yahya ${ }^{33}$ & Nigeria & $\begin{array}{l}\text { BC awareness, attitudes and } \\
\text { practice }\end{array}$ & $\begin{array}{l}\text { Cross-sectional descriptive } \\
\text { community-based study }\end{array}$ & $\begin{array}{l}\text { Interviewer-administered } \\
\text { structured validated } \\
\text { questionnaire ( } 23 \text { items) }\end{array}$ & $\begin{array}{l}\text { States validated questionnaire, but no } \\
\text { further information provided }\end{array}$ \\
\hline Hyacinth et al. ${ }^{34}$ & Nigeria & $\begin{array}{l}\text { CC and Pap smear awareness and } \\
\text { utilisation }\end{array}$ & Cross-sectional survey & Validated questionnaire & $\begin{array}{l}\text { Referenced an unpublished thesis and } \\
\text { one other study which pretested the } \\
\text { questionnaire with participants }(n=20) \\
\text { before the final questionnaire was } \\
\text { developed }\end{array}$ \\
\hline $\begin{array}{l}\text { Oluwatosin }{ }^{35} ; \\
\text { Oluwatosin and } \\
\text { Oladepo }\end{array}$ & Nigeria & $\begin{array}{l}\text { a) Rural women's perceptions } \\
\text { of BC and its early detection } \\
\text { measures } \\
\text { b) Knowledge of BC and its early } \\
\text { detection measures }\end{array}$ & Cross-sectional survey & $\begin{array}{l}\text { Structured questionnaire } \\
\text { with } 4 \text { questions \& } 56 \text { items }\end{array}$ & $\begin{array}{l}\text { Literature, focus groups to refine, } \\
\text { test / retest reliability = } 0.95 ; \\
\text { One article specified } 20 \text { women } \\
\text { participated in test/retest reliability }\end{array}$ \\
\hline Oluwatosin ${ }^{37}$ & Nigeria & $\begin{array}{l}\text { BC: Assessment of risk factors and } \\
\text { predictive factors for breast } \\
\text { examination }\end{array}$ & Cross-sectional survey & $\begin{array}{l}\text { Self-developed three-part } \\
\text { semi-structured } \\
\text { questionnaire; one } \\
\text { section used a validated } \\
\text { tool (Gail Model); } \\
\text { questionnaire tested for } \\
\text { reliability }\end{array}$ & $\begin{array}{l}\text { Test } / \text { retest reliability score }=0.95 \\
\text { tested with group of women with } \\
\text { similar characteristics to study sample }\end{array}$ \\
\hline Akhigbe and Omuemo ${ }^{39}$ & Nigeria & $\begin{array}{l}\text { Knowledge, attitudes and practice } \\
\text { of BC screening }\end{array}$ & $\begin{array}{l}\text { Cross-sectional descriptive } \\
\text { survey }\end{array}$ & $\begin{array}{l}\text { Pre-tested self-administered } \\
\text { questionnaire }\end{array}$ & $\begin{array}{l}\text { Pretest; no further details given on } \\
\text { pretest process and function of the } \\
\text { same }\end{array}$ \\
\hline Kayode et al. ${ }^{40}$ & Nigeria & $\begin{array}{l}\text { Knowledge, attitude and practice } \\
\text { of breast self-examination }\end{array}$ & $\begin{array}{l}\text { Descriptive cross-sectional } \\
\text { survey }\end{array}$ & $\begin{array}{l}\text { Pre-tested structured } \\
\text { questionnaire }\end{array}$ & $\begin{array}{l}\text { Pre-tested; no further details given on } \\
\text { the pretest process and function of the } \\
\text { same }\end{array}$ \\
\hline $\begin{array}{l}\text { Shepherd and } \\
\text { Mclnerney }\end{array}$ & Sierra Leone & BC knowledge & $\begin{array}{l}\text { Quantitative descriptive- } \\
\text { exploratory design }\end{array}$ & Questionnaire & $\begin{array}{l}\text { Pilot study to test reliability }(n=5) \text {; no } \\
\text { results provided }\end{array}$ \\
\hline
\end{tabular}


TABLE 2 (Continues...): Symptom awareness tools identified, some validation details provided.

\begin{tabular}{|c|c|c|c|c|c|}
\hline Study & Country & Focus & Design & Tools & Evidence of validity \\
\hline Obaji et al. ${ }^{42}$ & Nigeria & $\begin{array}{l}\text { Awareness and practice of breast } \\
\text { self-examination }\end{array}$ & $\begin{array}{l}\text { Cross-sectional descriptive } \\
\text { study }\end{array}$ & $\begin{array}{l}\text { Interviewer-administered } \\
\text { questionnaire }\end{array}$ & $\begin{array}{l}\text { Validated and pre-tested with a } \\
\text { separate sample of women }\end{array}$ \\
\hline Lyimo and Beran ${ }^{43}$ & Tanzania & $\begin{array}{l}\text { CC screening: Demographic, } \\
\text { knowledge, attitudinal, and } \\
\text { accessibility factors }\end{array}$ & Cross-sectional survey & Structured questionnaire & $\begin{array}{l}\text { Pilot testing in similar context, } \\
\text { identification and modification of } \\
\text { problematic questions }\end{array}$ \\
\hline Mingo $^{44}$ & Botswana & CC: Awareness and screening & Hospital-based survey & Questionnaire & $\begin{array}{l}\text { Content validity }(n=3) \text { and revised } \\
\text { questionnaire accordingly }\end{array}$ \\
\hline Mupepi et al. ${ }^{45}$ & Zimbabwe & $\begin{array}{l}\text { Knowledge, attitudes and } \\
\text { demographic factors influencing } \\
\text { CC screening behaviour }\end{array}$ & $\begin{array}{l}\text { Cross-sectional community } \\
\text { survey }\end{array}$ & Questionnaire & $\begin{array}{l}\text { Six focus groups of eight participants } \\
\text { each }(n=48) \text { to test content and } \\
\text { construct validity }\end{array}$ \\
\hline Kiguli-Malwadde et al. ${ }^{46}$ & Uganda & $\begin{array}{l}\text { Knowledge, attitude and practice } \\
\text { of women on } \mathrm{BC} \text { and } \\
\text { mammography }\end{array}$ & $\begin{array}{l}\text { Cross-sectional descriptive } \\
\text { survey }\end{array}$ & $\begin{array}{l}\text { Interviewer-administered } \\
\text { questionnaire }\end{array}$ & $\begin{array}{l}\text { Content validity - questionnaire } \\
\text { reviewed for information quality and } \\
\text { legitimacy and relevant corrections } \\
\text { made }\end{array}$ \\
\hline Mugivhi et al. ${ }^{47}$ & South Africa & $\begin{array}{l}\text { Rural women's knowledge of } \\
\text { prevention and care related to BC }\end{array}$ & Quantitative survey & Structured interview & $\begin{array}{l}\text { Pre-tested for validity and reliability } \\
(n=10) \text { and relevant modifications } \\
\text { made to questionnaire }\end{array}$ \\
\hline Salaudeen et al. ${ }^{48}$ & Nigeria & $\begin{array}{l}\text { Knowledge and attitudes towards } \\
\mathrm{BC} \text { and breast self-examination }\end{array}$ & $\begin{array}{l}\text { Cross-sectional descriptive } \\
\text { survey }\end{array}$ & $\begin{array}{l}\text { Self-administered } \\
\text { questionnaire }\end{array}$ & $\begin{array}{l}\text { Pre-tested }(n=30) \text { and revisions made } \\
\text { accordingly }\end{array}$ \\
\hline Ramathuba et al. ${ }^{49}$ & South Africa & $\begin{array}{l}\mathrm{BC} \text { knowledge, attitudes and } \\
\text { screening practices }\end{array}$ & $\begin{array}{l}\text { Quantitative descriptive } \\
\text { cross-sectional design }\end{array}$ & $\begin{array}{l}\text { Closed-ended questionnaire } \\
\text { pretested for validity and } \\
\text { consistency }\end{array}$ & $\begin{array}{l}\text { Content (literature and peer review) } \\
\text { and construct validity; pretest reliability } \\
(n=15)\end{array}$ \\
\hline Okobia et al. ${ }^{50}$ & Nigeria & $\begin{array}{l}\text { BC: Knowledge, attitude and } \\
\text { practice }\end{array}$ & $\begin{array}{l}\text { Cross-sectional community } \\
\text { survey }\end{array}$ & $\begin{array}{l}\text { Interviewer-administered } \\
\text { questionnaire }\end{array}$ & $\begin{array}{l}\text { Content validity (literature and expert } \\
\text { review) pre-tested for reliability }(n=25) \\
\text { and ambiguous questions discarded }\end{array}$ \\
\hline Francis et al. ${ }^{51}$ & South Africa & $\begin{array}{l}\text { Attitudes and knowledge about } \\
\text { HPV and CC risk }\end{array}$ & Brief survey & Questionnaire & $\begin{array}{l}\text { Developed based on literature review } \\
\text { (articles referenced), pilot tested and } \\
\text { revised with a clinic-based population } \\
\text { similar to the clinic sample }\end{array}$ \\
\hline Mwaka et al. ${ }^{52}$ & Uganda & $\begin{array}{l}\text { Community awareness of CC risk } \\
\text { factors and symptoms }\end{array}$ & $\begin{array}{l}\text { Cross-sectional population- } \\
\text { based survey }\end{array}$ & Structured questionnaire & $\begin{array}{l}\text { Developed based on literature review } \\
\text { (articles referenced) and pilot test }\end{array}$ \\
\hline
\end{tabular}

TABLE 3: Symptom awareness tools identified, thorough validation.

\begin{tabular}{|c|c|c|c|c|}
\hline Study & Country & Focus & Design & Tools \\
\hline Naanyu et al. ${ }^{53}$ & Kenya & Lay perceptions of BC in Western Kenya & Cross-sectional survey & $\begin{array}{l}\text { BCAM adapted opinions about causes, symptoms, severity and } \\
\text { treatment of BC captured as free-text responses to open-ended } \\
\text { questions added to the BCAM tool. }\end{array}$ \\
\hline
\end{tabular}

$\mathrm{BC}$, breast cancer; BCAM, breast cancer awareness measure.

cancer, the ways in which one may know first that she or he has this condition?' (p. 149) The questionnaire was translated into Kiswahili, Kenya's national language, and this version was subjected to content validation via three focus group discussions consisting of men and women without cancer aged 18 years and above, attending non-cancer outpatient clinics.

Wachira et al..$^{54}$ focused on the validation of the BCAM in a Kenyan setting, based their work on 1061 women and an additional 48 women who participated in six cognitive focus group discussions. The authors opted to use BCAM in the absence of locally validated tools applicable in the Kenyan context. Of specific interest to this research team were two BCAM domains, breast awareness and perceived barriers to screening, which the Kenyan researchers associated with delays in timely interventions to enhance early breast cancer detection. Cognitive focus group interviews revealed that compound questions in the BCAM knowledge domain (for example, 'do you think discharge or bleeding [italics added] from your nipple could be a sign of breast cancer?') were confusing to participants, who recommended that these questions be rephrased for clarity. The study observed variances in cultural interpretation of some items as well as nuances around translation of BCAM items into Kiswahili. For example, participants requested clarification on the BCAM question 'do you think that redness of your breast skin could be a sign of breast cancer', noting that unless the top surface of the skin peels off, dark skin would not usually turn red. This resulted in rephrasing of the question to read 'change in skin colour' in lieu of redness for contextual relevance.

\section{Discussion}

Our scoping review provides a synthesis of research ${ }^{12}$ on tools used to measure symptom awareness in SSA and determine if such tools have been validated in SSA settings. In this regard, our review identified gaps in SSA breast and cervical cancer tool validation literature by presenting the extent of research and how this research was conducted ${ }^{11}$ in the period between 1997 and 2017. Scoping reviews are useful in various research aspects, including: examining the extent, range and nature of research activity; establishing the relevance of conducting a full systematic review; succinctly presenting and circulating research results; and identifying gaps in literature. ${ }^{9}$ In addressing how the research was conducted, the scoping review was limited to a narrative descriptive account of studies included and not a detailed analysis of the quality of these studies, which would be possible in a systematic review. ${ }^{9}$ 
Our findings demonstrate that several tools have been utilised to measure breast and cervical cancer in SSA contexts. SSA countries featured in this review are Botswana, ${ }^{44}$ Cameroon, ${ }^{29}$ Democratic Republic of Congo, ${ }^{19}$ Ghana, ${ }^{3}$ Kenya, ${ }^{20,23,26,54,55}$ Nigeria, ${ }^{21,22,24,28,35,36,37,39,40,42,48,50}$ Sierra Leone, ${ }^{41}$ South Africa, ${ }^{18,27,32,47,49,51}$ Tanzania, ${ }^{25,30,31,43}$ Uganda, ${ }^{15,16,38,46,52}$ and Zimbabwe. ${ }^{43}$ Of the 41 SSA studies reviewed, 20 studies utilised tools that were not validated. $15,16,17,18,19,20,21,22,23,24,25,26,27,28,29,30,31,32$ The other 21 studies identified tools used and offered information of varying detail regarding validation processes. ${ }^{33,34,35,36,37,38,39,40,41,42,43,44,45,46,47,48,49,50,51,52,53,54}$ with only two of these demonstrating detailed and systematic tool validation processes.53,54 Even so, these two studies are limited in that they show evidence of thorough validation focused on (1) breast cancer but not cervical cancer and (2) only two of the BCAM domains, namely knowledge and/ or perceptions of breast cancer and barriers to screening.

Twenty of the 41 studies reviewed were on breast cancer. Of these 20, six utilised tools that were not validated, 3,4,17,22,24,28 while 14 used validated tools, $, 33,35,36,37,39,40,41,42,46,47,48,49,50,53,54$ including the (1) single study that yielded two articles ${ }^{35,36}$ and (2) two studies that furnished detailed accounts of their validation process. ${ }^{53,54}$ Eighteen of the 41 studies reviewed focused on cervical cancer themes. Of these 18, 11 studies utilised tools that were not validated, ${ }^{15,16,18,19,20,21,23,25,26,29,31}$ while seven utilised validated tools..$^{34,38,43,44,45,51,52}$ Overall, more breast cancer studies (14) utilised validated tools than cervical cancer studies (7), most of which (11) utilised tools that were not validated. Of the 41 studies, one combined breast and cervical cancer themes, ${ }^{32}$ while two studies investigated cancer symptom awareness in general but also made mention of breast and cervical cancer symptom awareness among women in SSA. ${ }^{27,30}$ All three studies used tools that were not validated.

\section{Conclusion}

Our results point to the dearth of comprehensively validated and culturally relevant tools to measure breast and cervical cancer symptom awareness in the SSA context and the need for systematic efforts to develop and validate such tools. These findings are consistent with a study on understanding low cervical cancer screening in Uganda, which noted lack of validated tools in African settings. ${ }^{51}$ Using consistent and reliable measures in cancer studies contributes to the quality of research results, ${ }^{56}$ which, in turn, will inform oncology practice in so far as 'standardised, valid measurement is essential for monitoring levels of cancer awareness, examining its risk factors and consequences, and evaluating interventions to promote it'. ${ }^{.5}$

Furthermore, validated tools should be culturally relevant for their intended study populations. ${ }^{53,54,57}$ The Cancer Awareness Measure (CAM) and the Awareness and Beliefs about Cancer $(\mathrm{ABC})$ tools were developed in the UK to assess cancer awareness in the public; they include generic cancer awareness and cancer-specific measures for breast cancer (BCAM) and cervical cancer (CCAM) ${ }^{58}$ These tools could be of value in SSA; however, as they were developed in a very different sociocultural setting, they are likely to need adaptation for use in SSA. In our specific study context, validated tools that are culturally relevant in SSA settings will serve as standardised comparative measures to (1) assess breast and cervical cancer awareness, knowledge and beliefs; and (2) enable precise appraisal of breast and cervical cancer awareness interventions. Our findings have informed the development of an African Women Awareness of CANcer [AWACAN] tool to measure breast and cervical cancer awareness.

\section{Acknowledgements Competing interests}

The authors declare that they have no financial or personal relationships that may have inappropriately influenced them in writing this article.

\section{Authors' contributions}

J.M., F.M.W., S.E.S. and A.D.M. initiated the study and developed the study protocol. J.N.G. conducted the literature search, drafted the manuscript, incorporated revisions and prepared the final draft. J.M., F.M.W. and S.E.S. reviewed the articles for eligibility. All the authors reviewed the draft and approved the final manuscript.

\section{Funding}

This scoping review is part of a project jointly funded by the South African Medical Research Council, MRC UK (via the Newton Fund), GlaxoSmithKline Africa Non-Communicable Disease Open Lab (via a supporting grant Project Number: 023), University of Cape Town and the Cancer Association of South Africa.

This research is linked to the CanTest Collaborative, which is funded by Cancer Research UK [C8640/A23385], of which Fiona M. Walter is Director. The funders had no role in the study design, data collection or decision to publish. Authors retained control of the final content of the publication.

\section{Data availability statement}

Data sharing is not applicable to this article as no new data were created or analysed in this study.

\section{Disclaimer}

The views expressed in the submitted article are those of the authors and not the official position of any of the funders or institutions represented.

\section{References}

1. Bray F, Ferlay J, Soerjomataram I, Siegel RL, Torre LA, Jemal A. Global Cancer Statistics 2018: GLOBOCAN estimates of incidence and mortality worldwide for 36 cancers in 185 countries. CA Cancer J Clin [serial online]. 2018[cited 2018 Sept 18];68(6):394-424. Available from: https://onlinelibrary.wiley.com/doi/ Sept 18];68(6):394-424
full/10.3322/caac.21492 
2. Emery JD, Shaw K, Williams B, et al. The role of primary care in early detection and follow-up of cancer. Nat Rev Clin Oncol. 2014;11(1):38. https://doi.org/10.1038/ nrclinonc.2013.212

3. Clegg-Lamptey J, Dakubo J, Attobra Y. Why do breast cancer patients report late or abscond during treatment in Ghana? A pilot study. Ghana Med J. 2009;43(3):127-131. https://doi.org/10.4314/gmj.v43i3.55338

4. Ukwenya AY, Yusufu LD, Nmadu PD, Garba ES, Ahmed A. Delayed treatment of symptomatic breast cancer: The experience from Kaduna, Nigeria. S Afr J Surg. 2008;46(4):106-110.

5. Gyenwali D, Pariyar J, Onta SR. Factors associated with late diagnosis of cervical cancer in Nepal. Asian Pacific J Cancer Prev. 2013;14(7):4373-4737. https://doi. org/10.7314/APJCP.2013.14.7.4373

6. Macleod U, Mitchell ED, Burgess C, Macdonald S, Ramirez AJ. Risk factor for delayed presentation and referral of symptomatic cancer: Evidence for common cancers. Br J Cancer. 2009;101(S2):S92. https://doi.org/10.1038/sj.bjc 6605398

7. Rubin $G$, Berendsen $A$, Crawford $S M$, et al. The expanding role of primary care in cancer control. Lancet Oncol. 2015;16(12):1231-1272. https://doi.org/10.1016/ S1470-2045(15)00205-3

8. Devi B, Tang T, Corbex M. Reducing by half the percentage of late-stage presentation from breast and cervix cancer over 4 years: A pilot study of clinica downstaging in Sarawak, Malaysia. Ann Oncol. 2007;18(7):1172-1176. https:// doi.org/10.1093/annonc/mdm105

9. ArkseyH, O'MalleyL.Scoping studies:Towards a methodological framework. IntJ Soc Res Methodol. 2005;8:19-32. https://doi.org/10.1080/1364557032000119616

10. Levac D, Colquhoun H, O'Brien KK. Scoping studies: Advancing the methodology. Implement Sci. 2010; 5:69. [PMID: 20854677]. https://doi.org/10.1186/1748-59085-69

11. Peters MD, Godfrey CM, Khalil H, Mclnerney P, Parker D, Soares CB. Guidance for conducting systematic scoping reviews. Int J Evid-based Healthc. 2015;13(3): 141-146. https://doi.org/10.1097/XEB.0000000000000050

12. Colquhoun HL, Levac D, O'Brien KK, et al. Scoping reviews: Time for clarity in definition, methods, and reporting. J Clin Epidemiol. 2014;67:1291-1294. [PMID: 25034198]. https://doi.org/10.1016/j.jclinepi.2014.03.01

13. Bolarinwa OA. Principles and methods of validity and reliability testing of questionnaires used in social and health science researches. Nigerian Postgrad Med J. 2015;22(4):195. https://doi.org/10.4103/1117-1936.173959

14. Moher D, Liberati A, Tetzlaff J, Altman DG, Prisma Group. Preferred reporting items for systematic reviews and meta-analyses: The PRISMA statement. PLoS Med. 2009;6(7):e1000097.

15. Mukama T, Ndejjo R, Musabyimana A, Halage AA, Musoke D. Women's knowledge and attitudes towards cervical cancer prevention: A cross sectional study in Eastern Uganda. BMC Women's Health. 2017;17(1):9. https://doi.org/10.1186/ s12905-017-0365-3

16. Ndejjo R, Mukama T, Musabyimana A, Musoke D. Uptake of cervical cancer screening and associated factors among women in Rural Uganda: A cross sectional study. PLoS One. 2016;11(2):e0149696. https://doi.org/10.1371/journal.pone. 0149696

17. Azubuike SO, Celestina UO. Breast cancer: The perspective of Northern Nigerian women. Int J Prev Med. 2015;6:130. https://doi.org/10.4103/2008-7802.172803

18. Dreyer G, Van der Merwe FH, Botha MH, Snyman LC, Constant D, Harvey J. School-based human papillomavirus vaccination: An opportunity to increase
knowledge about cervical cancer and improve uptake of screening. S Afr Med J. 2015;105(11):912-919. https://doi.org/10.7196/SAMJ.2015.v105i11.9814

19. Ali-Risasi C, Mulumba P, Verdonck K, VandenBroeck D, Praet M. Knowledge, attitude and practice about cancer of the uterine cervix among women living in Kinshasa, the Democratic Republic of Congo. BMC Women's Health. 2014;14:30. Kinshasa, the Democratic Republic of Congo.
https://doi.org/10.1186/1472-6874-14-30

20. Morema EN, Atieli HE, Onyango RO, Omondi JH, Ouma C. Determinants of cervical screening services uptake among 18-49 year old women seeking services at the Jaramogi Oginga Odinga Teaching and Referral Hospital, Kisumu, Kenya. BMC Health Serv Res. 2014;14:335. https://doi.org/10.1186/1472-6963-14-335

21. Ahmed SA, Sabitu K, Idris SH, Ahmed R. Knowledge, attitude and practice of cervical cancer screening among market women in Zaria, Nigeria. Niger Med J. 2013;54(5):316. https://doi.org/10.4103/0300-1652.122337

22. Azubuike SO, Okwuokei SO. Knowledge, attitude and practices of women towards breast cancer in Benin City, Nigeria. Ann Med Health Sci Res. 2013;3(2):155-160. https://doi.org/10.4103/2141-9248.113653

23. Sudenga SL, Rotich AF, Otieno WA, Smith JS. Knowledge, attitudes, practices, and perceived risk of cervical cancer among Kenyan women: Brief report. Int J Gynecol Cancer. 2013;23(5):895-899. https://doi.org/10.1097/IGC.0b013e31828e425c

24. Irurhe NK, Raji SB, Olowoyeji OA et al. Knowledge and awareness of Breast cancer among female secondary school students in Nigeria. Acad J Cancer Res. 2012;5:01-5

25. Kahesa C, Kjaer S, Mwaiselage J, et al. Determinants of acceptance of cervical cancer screening in Dar es Salaam, Tanzania. BMC Public Health. 2012;12:1093. https://doi.org/10.1186/1471-2458-12-1093

26. Were E, Nyaberi Z, Buziba N. Perceptions of risk and barriers to cervical cancer screening at Moi Teaching and Referral Hospital (MTRH), Eldoret, Kenya. Af Health Sci. 2011;11(1)

27. Maree JE, Wright SC. How would early detection be possible? An enquiry into cancer related knowledge, understanding and health seeking behaviour of urban black women in Tshwane, South Africa. Eur J Oncol Nurs. 2010;14(3):190-196. https://doi.org/10.1016/j.ejon.2009.10.009
28. Osime OC, Okojie O, Aigbekaen ET, Aigbekaen IJ. Knowledge attitude and practice about breast cancer among civil servants in Benin City, Nigeria. Ann Afr Med. 2008;7(4):192-197. https://doi.org/10.4103/1596-3519.55654

29. Tebeu PM, Major AL, Rapiti E, et al. The attitude and knowledge of cervical cancer by Cameroonian women; a clinical survey conducted in Maroua, the capital of Far North Province of Cameroon. Int J Gynecol Cancer. 2008;18(4):761-765. https:// doi.org/10.1111/j.1525-1438.2007.01066.x

30. Kazaura, MR, Kombe D, Yuma S, Mtiro H, Mlawa G. Health seeking behavior among cancer patients attending Ocean Road Cancer Institute, Tanzania. East Afr J Public Health 2007;4(1):19-22.

31. Kidanto HL, Kilewo CD, Moshiro C. Cancer of the cervix: Knowledge and attitudes of female patients admitted at Muhimbili National Hospital, Dar-es-Salaam. East Afr Med J. 2002;79(9):467-475. https://doi.org/10.4314/eamj.v79i9.9118

32. Pillay AL. Rural and urban South African women's awareness of cancers of the breast and cervix. Ethn Health. 2002;7(2):103-114. https://doi.org/10.1080/ 1355785022000038588

33. Omotara B, Yahya S, Amodu M, Bimba J. Awareness, attitude and practice of rura women regarding breast cancer in Northeast Nigeria. J Community Med Health Educ. 2012;2(5):1-4. https://doi.org/10.4172/2161-0711.1000148

34. Hyacinth $\mathrm{HI}$, Adekeye OA, Ibeh JN, Osoba T. Cervical cancer and pap smear awareness and utilization of pap smear test among Federal civil servants in North Central Nigeria. PLoS One. 2012;7(10):e46583. https://doi.org/10.1371/journal. pone. 0046583

35. Oluwatosin OA. Rural women's perception of breast cancer and its early-detection measures in Ibadan, Nigeria. Cancer Nurs. 2006;29(6):461-466. https://doi.org/ 10.1097/00002820-200611000-00006

36. Oluwatosin $\mathrm{OA}$, Oladepo $\mathrm{O}$. Knowledge of breast cancer and its early detection measures among rural women in Akinyele Local Government Area, Ibadan, Nigeria. BMC Cancer. 2006;6(1):271. https://doi.org/10.1186/1471-2407-6-271

37. Oluwatosin OA. Assessment of women's risk factors for breast cancer and predictors of the practice of breast examination in two rural areas near Ibadan Nigeria. Cancer Epidemiol. 2010;34(4):425-428. https://doi.org/10.1016/j. canep.2010.04.005

38. Twinomujuni C, Nuwaha F, Babirye JN. Understanding the low level of cervical Cancer screening in Masaka Uganda using the ASE model: A community-based survey. PLoS One. 2015;10(6):e0128498. https://doi.org/10.1371/journal.pone. 0128498

39. Akhigbe AO, Omuemu VO. Knowledge, attitudes and practice of breast cancer screening among female health workers in Nigerian urban city. BMC Cancer. 2009;9:203. https://doi.org/10.1186/1471-2407-9-203

40. Kayode FO, Akande TM, Osagbemi GK. Knowledge, attitude and practice of breast self-examination among female secondary school teachers in Ilorin, Nigeria. Eur J Sci Res. 2005;3:42-47.

41. Shepherd JH, Mclnerney PA. Knowledge of breast cancer in women in Sierra Leone. Curationis. 2006;29(3):70-77. https://doi.org/10.4102/curationis.v29i3.1105

42. Obaji NC, Elom HA, Agwu UM, Nwigwe CG, Ezeonu PO, Umeora OU. Awareness and practice of breast self. Examination among market women in Abakaliki, South East Nigeria. Ann Med Health Sci Res. 2013;3(1):7-12. https://doi. org/10.4103/2141-9248.109457

43. Lyimo FS, Beran TN. Demographic, knowledge, attitudinal, and accessibility factors associated with uptake of cervical cancer screening among women in a rural district of Tanzania: Three public policy implications. BMC Public Health. 2012;12(1):22. https://doi.org/10.1186/1471-2458-12-22

44. Mingo AM, Panozzo CA, DiAngi YT, et al. Cervical cancer awareness and screening in Botswana. Int J Gynecol Cancer. 2012;22(4):638-644. https://doi.org/10.1097/ IGC.0b013e318249470a

45. Mupepi SC, Sampselle CM, Johnson TR. Knowledge, attitudes, and demographic factors influencing cervical cancer screening behavior of Zimbabwean women. J Women's Health. 2011;20(6):943-952. https://doi.org/10.1089/ jwh.2010.2062

46. Kiguli-Malwadde, E, Mubuuke, GA, Businge, F, et al. Current knowledge, attitudes and practices of women on breast cancer and mammography at Mulago Hospital. Pan Afr Med J. 2010;5:9.

47. Mugivhi NH, Maree JE, Wright SC. Rural women's knowledge of prevention and care related to breast cancer. Curationis. 2009;32(2):38-45. https://doi org/10.4102/curationis.v32i2.928

48. Salaudeen AG, Akande TM, Musa OI. Knowledge and attitudes to breast cancer and breast self-examination among female undergraduates in a State in Nigeria. Eur J Soc Sci. 2009;3:157-165.

49. Ramathuba DU, Ratshirumbi CT, Mashamba TM. Knowledge, attitudes and practices toward breast cancer screening in a rural South African community Curationis. 2015;38(1):1-8. https://doi.org/10.4102/curationis.v32i2.928

50. Okobia MN, Bunker $\mathrm{CH}$, Okonofua FE, Osime U. Knowledge, attitude and practice of Nigerian women towards breast cancer: A cross-sectional study. World J Surg Oncol. 2006;4:11. [PMCID: PMC1397833] [PubMed: 16504034]. https://doi. org/10.1186/1477-7819-4-11

51. Francis SA, Nelson J, Liverpool J, et al. Examining attitudes and knowledge about HPV and cervical cancer risk among female clinic attendees in Johannesburg, South Africa. Vaccine. 2010;28(50):8026-8032. https://doi.org/10.1016/j. vaccine.2010.08.090

52. Mwaka AD, Orach CG, Were EM, Lyratzopoulos G, Wabinga H, Roland M. Awareness of cervical cancer risk factors and symptoms: Cross-sectional community survey in post-conflict northern Uganda. Health Expect. 2016;19(4):854-867. https://doi. org/10.1111/hex.12382 
53. Navanyu V, Asirwa CF, Wachira J, et al. Lay perceptions of breast cancer in Western Kenya. World J Clin Oncol. 2015;6(5):147. https://doi.org/10.5306/wjco.v6.i5.147

54. Wachira J, Busakhala A, Chite F, et al. Refining a questionnaire to assess breast cancer knowledge and barriers to screening in Kenya: Psychometric assessment of the BCAM. BMC Health Serv Res. 2017;17(1):110. https://doi.org/10.1186/ s12913-017-2058-x

55. Linsell L, Forbes LJ, Burgess C, Kapari M, Thurnham A, Ramirez AJ. Validation of a measurement tool to assess awareness of breast cancer. Eur J Cancer. 2010;46(8):1374-1381. https://doi.org/10.1016/j.ejca.2010.02.034
56. Souza AC, Alexandre NM, Guirardello ED. Psychometric properties in instruments evaluation of reliability and validity. Epidemiologia e Serviços de Saúde. 2017;26(3):649-659. https://doi.org/10.5123/S1679-49742017000300022

57. Pitcher S, Adams T, Van Wijk L, et al. Holistic sexuality post gynaecological cancer treatment: A review of recent literature. SA J Oncol. 2018;2(1):1-7. https://doi. org/10.4102/sajo.v2i0.40

58. Simon $A E$, Forbes $L J$, Boniface $D$, et al. An international measure of awareness and beliefs about cancer: Development and testing of the ABC. BMJ Open. 2012;2(6):e001758. https://doi.org/10.1136/bmjopen-2012-001758 


\section{Appendix 1}

\begin{tabular}{|c|c|c|c|}
\hline 1. Breast cancer & 14. Knowledge & 27. Scales & 40. Timely diagnosis \\
\hline 2. Cervical cancer & 15. Literacy & 28. Patterns & 41. Treatment \\
\hline 3. Symptom* & 16. Ignorance & 29. Measures & 42. Cancer control \\
\hline 4. Signs & 17. Culture & 30. Questions & 43. Cancer management \\
\hline 5. Symptom appraisal & 18. Stigma & 31. Validation & 44. Qualitative \\
\hline 6. Symptom interpretation & 19. Abscond & 32. Management & 45. Quantitative \\
\hline 7. Beliefs & 20. Awareness & 33. Disclosure & 46. Africa \\
\hline 8. Attitudes & 21. Understanding & 34. Report & 47. Sub-Saharan Africa OR Africa South of the Sahara \\
\hline 9. Expressions & 22. Construct* & 35. Risk* & 48. Low resource countries \\
\hline 10. Communication & 23. Expectations & 36. Barriers & 49. Rural \\
\hline 11. Conceptualization & 24. Challenges & 37. Facilitators & 50. Urban \\
\hline 12. Lay perceptions & 25. Opportunities & 38. Screening & \\
\hline 13. Behaviour & 26. Tools & 39. Delayed diagnosis & \\
\hline
\end{tabular}

*, represents root words utilised in the search e.g. symptom* includes all words that contain the root word symptom e.g. symptomatic and symptoms. FIGURE 1-A1: List of potential search terms from existing literature. 